\title{
Bir Diplomatın Gayri Resmî Mücadelesi: Hamdullah Suphi'nin Bilinmeyen Gagauz Müdafaası
}

\section{The Unofficial Struggle of a Diplomate: Unknown Gagauz Defense of Hamdullah Suphi}

\author{
Selcen Özyurt Ulutaş* (]
}

*Dr. Öğretim Üyesi, Uşak Üniversitesi, Fen-Edebiyat Fakültesi, Tarih Bölümü, Uşak, Türkiye

ORCID: S.Ö.U. 0000-0002-7235-3548

Sorumlu yazar/Corresponding author: Selcen Özyurt Ulutaş,

Uşak Üniversitesi, Fen-Edebiyat Fakültesi, Tarih Bölümü, Uşak, Türkiye

E-posta/E-mail: selcen.ozyurt@usak.edu.tr

Başvuru/Submitted: 11.02 .2020 Revizyon Talebi/Revision Requested: 24.11.2020

Son Revizyon/Last Revision Received: 25.11.2020

Kabul/Accepted: 15.12 .2020

\section{Atıf/Citation:}

Ozyurt Ulutas, Selcen. "Bir Diplomatın Gayri Resmî Mücadelesi: Hamdullah Suphi'nin Bilinmeyen Gagauz Müdafaası" Tarih DergisiTurkish Journal of History, 72 (2020): 187-206. https://doi.org/10.26650/iutd.687687

\section{Öz}

Gagauz Türkleri hiç şüphe yoktur ki büyük Türk milletinin en müstesna topluluklarından biridir. Dilleriyle, inançlarıyla, kültürleriyle Gagauzlar yıllara meydan okumuş ve kimliklerini muhafaza edebilmişlerdir. Hayli uzun yıllar varlıklarından dahi haberdar olunamayan Gagauzlar, Türkiye Cumhuriyeti'nin raporlarına 1930'lu yıllardan itibaren girmeye başlamışlardır. İlgili yıllarda farklı büyükelçilik raporlarıyla devlet erkânına Gagauzlar hakkında bilgi verilmiştir. 1932 'den itibaren ise Cumhuriyet ve Ulus gazetelerinde ilk defa Gagauzlar Türk toplumuna takdim edilmiştir. Zaman içerisinde Gagauzlara dair bilgiler arttıkça Türk Devleti'nin ve milletinin de onlara teveccühü ziyadeleşmiştir. Özellikle Hamdullah Suphi Tanrı̈ver'in gayretleri çok önemlidir. O, Gagauzları Türkiye'ye getirmek için çok çaba sarf etmiştir. Ancak hiç beklemediği bazı sorunlarla karşılaşmış ve çetin bir mücadeleye girişmiştir. Çalışmada titiz bir taramayla Hamdullah Suphi Tanrı̈̈ver'in bilinmeyen gayretlerine yer verilecektir.

Anahtar sözcükler: Ulus Gazetesi, Cumhuriyet Gazetesi, Gagauz, Hristiyan Türkler, Hamdullah Suphi Tanrı̈ver, Büyükelçilik Raporları

\section{ABSTRACT}

There is no doubt that the Gagauz Turks are one of the most exceptional groups of the great Turkish nation. With their tongues, beliefs and cultures, Gagauz people shine like a star in their geography. For many years, those who ruled the state for various reasons could not be aware of Gagauz. However, the bureaucrats of the newly established Turkish state started to compile information about the Gagauz people because, according to archive records, we start to see Gagauz people in the embassy reports after 1930. After 1932, news about the Gagauz began to appear in the Ulus and Cumhuriyet newspapers. The purpose of these news was to inform to the Turkish people about the Gagauz people. As the information about the Gagauz increased in time, the favor of the Turkish state and its nation became more frequent. Especially Hamdullah Suphi Bey's efforts are very important. He made a great effort to bring the Gagauz to Turkey. However, he faced a number of problems he had never expected and engaged in a tough fight..

Keywords: Ulus Newspaper, Cumhuriyet Newspaper, Gagauz, Chirstian Turks, Hamdullah Suphi Tanrı̈ver, Embassy Reports 


\section{Extended Abstract}

The 1920-1940 period were the most difficult years for Turkey in all respects. One of the many problems faced by the Turkish nation (which emerged from the First World War and struggle for liberation against invasions), and its rulers was the issue of population and identity. The reproduction of the Turkish nation, which had reached the point of extinction as a result of long years of wars, as well as the achievement of a certain identity understanding formed the essence of the population policies of the period. In order to achieve this, every opportunity was used. In this context, the policy of increasing the population was followed in the first years of the republic. While measures were taken to reduce deaths, remedies were sought to increase fertility. Another way to increase the population was to bring the Muslim Turkish population, which was an Ottoman remnant and lived outside Anatolia, to the homeland. The exchange agreements signed with various Balkan countries, especially Greece, and Hatay's accession to the homeland were important stages in these efforts.

As it is known, the Agreement and Protocol on the Exchange of Turkish-Greek People was signed in Lausanne on 30 January 1923. Subsequently, after being accepted in the Turkish Grand National Assembly, joint commissions were established and the process was initiated. Only then did another problem arise: Who would define the adjective exchangee? Because different nations, who lived together for hundreds of years, defining themselves after the empire became a mystery in itself. By means of marriages, births, exchanges and migrations, past identities emerged from each other. This situation must have become a problem for the exchange commission that was established, as the commission was only able to determine the identity that would be recognized as the determining factor for the exchange procedures four years later at its meeting on 31 March 1927. As a result of the meeting, the commission decided to interpret and apply the terms "Muslim Religion" and "Greek Orthodox Religion" regardless of race. The decision of the Exchange Commission in 1927 directly affected the definition of citizen of the newly established state and also the fate of the Gagauz people within the framework of our topic.

The greatest concern of Hamdullah Suphi Tanrı̈ver was that the Gagauz people would not be accepted by the state because they were Christians. For this reason, he gave examples showing that religious differences within the same nation would not be a problem, and he offered material evidence for his ideas and tried to prevent possible objections. Unfortunately, Hamdullah Suphi Tanriöver will be justified in his concerns, in a sense, what he fears will happen to him. Suphi Bey, who could not get the turns that he expected from the government and could not do what he wanted to do, resorted to a new path in order to realize his plans. Using the power of the press, he wanted to tell the Turkish nation who the Gagauz people were and the difficult conditions they were in. Hamdullah Suphi Tanriöver tried to introduce 
the Gagauz people to the Turkish people with the help of people he knew from the Turkish press. Possibly increasing the visibility of the Gagauz society will also create a public and state officials for their transport to Turkey can not remain indifferent to consider.

The writings of Yaşar Nabi Nayır about the Gagauz people were really effective. Because, following the series of articles in question, letters written directly to İsmet İnönü by Tevfik Kâmil Koperler, who was the Ambassador in Madrid at that time, starting from 18 January 1936 are the most important proofs of this. What Tevfik Kâmil Koperler wrote would affect the decisions of the state dignitaries. Kâmil Koperler, who was also a law professor, served as the Clerk of the Lausanne Conference Turkish Delegation. However, more importantly, he was the Head of the Turkish Delegation of the Turkish Greek Population Exchange. Direct Addressing the Prime Minister Ismet Inonu, and reports that he wrote the Gagauz and that should not come to Turkey that Turkey has written. According to Kâmil Bey, who was personally present in Lausanne where the exchange decision was made, possible immigration is against Lausanne. The situation has been clarified and a sample of the Gagauz, if Turkey has even said that if they were in built-up to Greece because of the scope of the Exchange Agreement to be Orthodox.

In this historical process that the construction of national identity, national identity, they also define the founders of the newly founded Republic of Turkey. Of course, it was a painful process for the state, which was the remnant of the empire, to establish a new Turkish identity from the population dispersed from the Middle East to the Balkans. Although the main element of Turkish identity was seen as the ethnic element, in fact the dominant element of national identity for the founders of this period was the Islam religion. It has been established as a manifestation of the past. Because the Balkan nations always emphasized their being "Orthodox" when defining themselves. In these years when nations were almost rebuilt, the administrators chose "Islam" as the main backbone of the Turkish identity under the conditions of the period. In a sense, the 1927 Exchange Commission decision made it official. 


\title{
Giriş
}

Gagauz Türklerinin, Türkiye Cumhuriyeti tarafindan fark edilmesi ile onlarla gerçek anlamda alakadar olunması arasında ciddi bir zaman farkı vardır. Arşivlerimize göre, Gagauzlar hakkında Türk Devleti'ne resmi düzeyde bilgi veren ilk kişi Köstence Konsolosu Mehmet Ragıp (İlseven) Bey’dir. Onun 14.10.1930 tarihli ve 1228/189 sayılı raporunda şu ifadeleri dikkat çekicidir:

\begin{abstract}
“Romanya'nın Besarabya ve Dobruca kıtalarında, Bulgaristan'ın Varna Sancağında Gagauz denilen küçük bir halk vardır ki ana dili Türkçe, mezhebi de Hristiyan Ortodoks 'tur. Münkariz Türk padişahliğının idaresi altında beş altı asır yaşayan bu memleketler de mezkûr Türk kabilesinin diğer ırkdaşlarından itikatça ayrlarak Hristiyan mezhebinde kalmış olması, asıl ve menşeinden bugün bihaber bulunması pek çok merak ve dikkatimi mucip olduğundan mazisi ve şimdiki hal ve vaz'ı hakkında tahkikata giriştim, bazı münevver kimselerden malûmat istedim ve topladım ki bu müteferrik malûmatın hulasası şudur... bunlar Türk idaresi altında dilleri Türkleşen eski Rumlardan ibaret bir klsım halktır, diyenler varsa da bu yanlış bir telakkidir. Esasen Türk oldukları halde Türklüğ̈̈ bırakarak İslavlaşan Bulgarların takma İslavliklarına dokunulmayan bir memlekette yaşayan Yunanlı bir ırkın- dinlerini ve Istanbul patrikliği ile irtibatlarını idame ettirmekle beraber- dillerini unutarak Türkçeyi ana dili addetmeleri akla uygun bir ihtimal değildir... Gagauzların öz aileleri içinde söyledikleri dil Deli-Orman Türk lehçesidir, erkekleri bulunduklarl yerlere göre Romence, Rusça, Bulgarca, Rumca dillerinden birini veya birkaçını bilirler, içlerinde ziraat, ticaret ve muhtelif küçük sanatlarla iştigal edenler, az çok zengin olanlar vardır; ilim ve hüner ve sahaların da sair ecnebi memleketlerdeki Türklerle aynı seviye de, aynı hal ve vaziyettedirler".
\end{abstract}

Buradaki ifadelerden de anlaşılacağı üzere Ragıp Bey kişisel merakı mucibince yaptığı araştırmaları, gözlemleri derlemiş ve Dış İşleri Bakanlığına tafsilatlı bir rapor takdim etmiştir. Osmanlı Devleti'nin dağılmasına şahitlik etmiş, yeni Türkiye Cumhuriyeti’nin kuruluşunda yer almış bir devlet adamı olarak Mehmet Ragıp Bey’in tespit ve tahlilleri çok önemlidir. Özellikle Bulgarların ülkelerindeki Türklere yönelik politikalarını bizzat yaşayarak gören Ragıp Bey, Bulgarların topraklarında ana dili Türkçe olan Rumların yaşamalarına müsaade etmeyeceğini net bir şekilde ifade etmiştir. Raporda farklı bilim insanlarının Gagauzların menşeine dair görüşlerini de derleyen Mehmet Ragıp Bey, Gagauzların Slav veya Rum menşeli oldukları iddialarını kesin bir dille reddetmiştir. Kayıtlara giren ve Ragıp Bey'in şahsi gözlemlerine dayanan bu kıymetli belgeden sonra Gagauzlara dair ikinci elçilik raporu ise maalesef tüm araştırmalarımıza rağmen ismini tespit edemediğimiz Varna Konsolosu'na aittir. İki yıl sonra Dış İşleri Bakanlığı'na takdim edilen 12.03.1932 tarihli rapor şu ifadelerle başlamıştır:

1 CCA. 030.10.246.666.30. 
"Bu konsolosluk havzasında mezhepleri Ortodoks, Türkçe konuşur, pek çok köylü halkına buraya birkaç ay evvel tayin edildiğim zaman tesadüf etmiş ve bu halkın miktarlart ile menşeleri, adetleriyle ibadetleri ve tahsilleri ile meylettikleri milliyet hakkında layılyla tetkikatta bulunmayı bir vazife telakki eylemiş idim "’.

Konsolos Bey, tesadüfen karşılaştığını ifade ettiği Gagauzlar hakkında araştırma yapmayı kişisel bir vazife telakki etmiştir. Yedi sayfalık raporun ilk altı sayfasında Gagauzların kim olduklarına ve isimlerine dair genel bilgileri derleyen Varna Konsolosu sonuç kısmını ihtiva eden son sayfada kanaatlerini beyan etmiştir:

"Bunlar şimdiye kadar Türkler tarafindan layıkıla benimsenmediği ve kendi aralarında da alim, muharrir, siyasi, memur ve muallim yetişmediği için Türklere ve Türkiye'ye karşı alakai hissiyeleri neşvünema buldurulmamıştır. Şarkılarını Türkçe söylerler, dualarını Türkçe yaparlar. Romanya'da, Besarabya'da ve Bulgaristan'da mevcut bulunan bu Hristiyan Türkler memleketimize celbedildikleri ve aynı nesilden olan Anadolu Türkleriyle ihtilatları temin olunabildiği takdirde Ŏguz neslinden bir kütlenin Bulgarlaştırllmasının önüne geçilmiş olmakla beraber neslimize dolaylslyla tarihimize pek büyük bir hizmet ifa edilmiş olunur mütalaasında bulunduğumu ehemmiyetle arz eylerim Efendim. "’3

Rapordan da açıkça anlaşılacağı üzere daha evvel haklarında hiçbir malumatı olmayan, kendi şahsi gözlem ve tecrübeleri ile tanıdığı Gagauzların Türklüğü ile alakalı Konsolos Beyin en ufak bir şüphesi yoktur. Onlara sahip çıkılması gerektiğini, bunun millî bir vazife olduğunu beyan eden Konsolos Bey ilk defa Gagauzların Türkiye'ye nakledilmesini önermiştir. Bilindiği üzere daha sonra bu fikrin en ateşli savunucusu Hamdullah Suphi Tanrı̈ver olacaktır. 1930 ve 1932 tarihli iki rapor ile Türk Devleti sınırları dışında yaşayan ancak Hıristiyan olan Türklerden haberdar olunmuştur. Her iki konsolos da şüphesiz bir surette Gagauzların Türklüğüne vurgu yapmıştır. 1931-1944 yılları arasında Bükreş Büyükelçisi olarak görev yapan Hamdullah Suphi Tanrı̈ver de bütün görev süresi boyunca Gagauzların Türklügünü idarecilere ispat etmeye çalışmış ve onların Türkiye'ye nakledilmeleri için çaba sarf etmiştir. Fakat aşağıda da görüleceği üzere Hamdullah Suphi Tanrı̈ver'in heyecanını, düşüncelerini paylaşması ve kabul ettirmesi ciddi engellerle karşılaşmıştır.

\section{Yeni Bir Devletin Kuruluşu ve Ulus İnşası}

1920-1940 dönemi her bakımdan Türkiye için zor yıllar olmuştur. I. Dünya Savaşı'ndan çıkan, işgallere karşı destansı kurtuluş mücadelesi veren Türk milletinin ve idarecilerin karşılaştığı sorunlardan biri de nüfus ve kimlik meselesidir. Uzun yıllar süren savaşlar neticesinde sayısal olarak tükenme noktasına gelen Türk milletinin çoğaltılmasının yanı sıra bu insanların belirli bir kimlik anlayışına kavuşmaları dönemin nüfus politikalarının

2 CCA. 030.10.246.666.30.

3 CCA. 030.10.246.666.30. 
özünü oluşturmuştur. Bunun sağlanabilmesi için de her olanak kullanılmıştır ${ }^{4}$. Bu bağlamda cumhuriyetin ilk yıllarında nüfusu artırma politikası izlenmiştir. Ölümlerin azalması için önlemler alınırken bir yandan da doğumları artırma çareleri aranmıştır . Nüfusu artırmaya yönelik bir başka yol ise Osmanlı bakiyesi olan ve Anadolu dışında yaşayan Müslüman Türk nüfusun anavatana getirilmesidir. Başta Yunanistan olmak üzere çeşitli Balkan ülkeleriyle imzalanan mübadele anlaşmaları ve Hatay’ın anavatana katılması bu çabanın önemli aşamalarıdır.

Bilindiği üzere Türk-Rum Ahalinin Mübadelesine Dair Mukavelenâme ve Protokol, Lozan'da 30 Kanunisanî 1923 'te imzalanmıştır. Akabinde TBMM'de kabul edildikten sonra ortak komisyonlar kurularak süreç başlatılmıştır. Ancak o zaman da başka bir sorun zuhur etmiştir; mübadil sıfatı kimleri tanımlayacaktır? Çünkü yüzlerce yıl birlikte yaşayan farklı ulusların, imparatorluktan sonra kendilerini tanımlamaları başlı başına bir muamma haline geldi. Evlilikler, doğumlar, din değiştirmeler, göçler derken birbirinin içine geçmiş birçok kimlik ortaya çıkmıştı. Bu durum kurulan mübadele komisyonu için de bir sorun hâline gelmiş olmalı ki, komisyon mübadele işlemleri için belirleyici faktör olarak tanınacak kimliği ancak dört yıl sonra 31 Mart 1927 tarihinde yaptığı toplantıda belirleyebildi. Söz konusu toplantının sonucunda komisyon "Müslüman Dini” ve "Rum Ortodoks Dini” tabirlerinin 1rk gözetilmeksizin yorumlanıp uygulanmasına karar verdi. Mübadele komisyonunun 1927'de bu kararı alması yeni kurulan devletin vatandaş tanımını da ayrıca konumuz çerçevesinde Gagauzların akıbetini de doğrudan etkilemiştir.

Genç cumhuriyet kurulurken ifade edildiği üzere imparatorluk bakiyesi olması hasebiyle kendisine ana kimlik inşa etmesi gerekmekteydi. Elbette bu kimlik Türklük idi. Ancak öte yandan şurası da açıktır ki etnik veya ulusal kimlikler toplumsal bir kurguyla yaratılır. Bu yeniden yapılanmaya kaynaklık eden gerçeklik unsurları bağlamında etniklik göreli olarak daha doğal bir olgu iken; ulus nispeten siyasal bir oluşumdur. Elbette her iki kimlik için de ortak kültür, ortak tarih, ortak toprak ve dil gibi unsurlar inşa süreci temelinde yeniden üretilmektedir. Genel olarak etnik kimliği de; "içinde yaşadı̆̆l daha geniş toplumla bütünleşmeyerek ortak ırk, dil, milliyet veya kültür bağına dayalı bir birlik oluşturan toplumsal grup ya da nüfus kategorisi" olarak tanımlamak mümkündür6́. Özetle topluluğun kendine verdiği bir ad, dil, belirli bir toprak, ruhsal yapının spesifik özellikleri, kültür ve gündelik hayat bir etnik topluluğun temel özellikleri olarak görülebilir ${ }^{7}$.

4 Adalet Ergenekon Çil, Cumhuriyetin İlk Yıllarında Nüfus Sorunu ve İskân Politikası, Yıldız Teknik Üniversitesi Sosyal Bilimler Enstitüsü, Basılmamış Doktora Tezi, İstanbul 1994, s. 297.

5 Çil, s. 55.

6 Remzi Yardımcı, Atatürkçü Düşüncede Ulusal Kimlik Bilinci Kavramı, İstanbul Üniversitesi Atatürk İlkeleri ve İnkılap Tarihi Enstitüsü, Basılmamış Doktora Tezi, İstanbul 1999, s. 16.

7 Yardimcı, s. 18. 
Buna mukabil ulusal kimliğin oluşumunda ise simgeler ve ritüeller belirleyicidir. Söz konusu teoriye göre topluluk, simgelerin kullanımı ve ulusun üyeleri olan bireylere güç veren törenlerin tekrarlanması aracılığı ile yaratılır. Kendilerini birleşmiş hissedebilecekleri özel olayları öne çıkartarak ve birliği tesis eden simgeler sergileyerek ulus kendisini ötekilerden ayıran sınırlar oluşturur. Kısaca ulusal kimliğin inşası, bireylerin kendilerindeki topluluk duygusunu geliştirme ve öne çıkarma gücü olan simgelerle özdeşleştirmelerini içeren karmaşık bir süreçtir. Bu özdeşleştirme süreci ise bireylerin yalnızca olmuş simgeleri benimsemeleri ile değil daha çok bunların sürekli yeniden yaratılmaları ve topluluğun yaşamı aracılığı ile geliştirdiği değişen koşullara göre yeniden anlamlar yüklemeleri şeklinde işler. Sonuç olarak konumuz bakımından Durkheim'in ulusal kimliğin inşasında inancın ne denli önemli olduğuna dair şu tespiti çok önemlidir; "herhangi bir güçteki bir kanaat aynı insan topluluğunca benimsendiğinde, bunun kaçınılmaz olarak dini bir karakter alması evrensel bir olgudur. Grubu oluşturan insanlar kendilerini ortak bir inanç ile birbirlerine bağlı hissederler"s.

Açıkça anlaşılacağı üzere ulusal kimliğin inşasında her ne kadar etnik kimlik ön planda görünüyor ise de esasında dinî değerler ve birliktelik daha baskındır. Balkan devletlerinin bağımsızlık hareketleri ise bunun en önemli delilidir. Çünkü Yunan, Sırp, Bulgar isyanları önce din adamları önderliğinde "Ortodoks" kimliği altında başlamıştır. Onlar kendilerini Ortodoks kimliğinden ayırmaksızın ulus devletleri için savaşmışlardır. Dönemin şartları göz önüne alındığında da Mübadele Komisyonunun 1927’de aldığı karar işte bu yüzden önemlidir. Komisyon belki farkında olarak ya da olmayarak "Müslüman-Türk" tanımıyla yeni kurulan devletin asli unsurunu ve kimliğini belirlemiştir.

\section{Gagauzlar Türk mü? Ne Kadar Türk?}

Hamdullah Suphi Tanrı̈ver uzun yıllar Türk Ocağı Başkanlığını yapmış ve yeni kurulan devlete ömrünün sonuna kadar hizmet etmiş önemli bir devlet adamıdır. Yeni kurulan devletin fizikî ve fikrî inşasında yer almıştır. Özellikle Türk Ocağı vasıtasıyla da sayısız hizmetlerde bulunmuştur. Bir fikir adamı olarak Hamdullah Suphi Tanrı̈ver'e göre devletler bir millî mefkûreye dayanır. Milletlerin dayanağı topraktır ve toprak kadar önemli olan manevi temellerdir. Bu manevi temellerin birincisi ise milliyettir. Millet kaynağını tarihten alır. Ona göre millî birliği sağlayan ana unsurlar dil, din ve emel birliğidir. Aynı dili konuşan insanlar nerede olursa olsun ne kadar zorlanırsa zorlansın birbirlerini sevecek ve birbirlerine yaklaşacaklardır'. Dil birliği onun için o denli önemlidir ki bir konuşmasında düşüncelerini şöyle ifade etmiştir:

8 Yardimc1, s. 30-33.

9 Murat Demir, Milli Eğitim Bakanı Hamdullah Suphi Tanriöver 'in Eğitim ve Kültür Anlayışı, Gazi Üniversitesi Eğitim Bilimleri Enstitüsü, Yayınlanmamış Yüksek Lisans Tezi, Ankara 2010, s. 116-119. 


\begin{abstract}
"Efendiler, milliyetimiz her şeyden fazla dilimizin içindedir. Dilimiz, atalarımızın bize bıraktı̆̆g en büyük servet, en büyük emanettir. Çok kısa müddet zarfinda Şamanilikten Buda mezhebine, Buda mezhebinden Nasturi Hıristiyanlı̆̆ına, Nasturi Hıristiyanlığından Müslümanlı̆̆a geçtiğimiz oldu. Fakat dilimizi bir defa değiştirmedik. Din değiş̧tikçe milliyet dil içine sı̆̆ınıyor, onu kelimelerinde mahfuz kalarak yaşamakta devam ediyordu. Yavrularımızın hafizasına Türkçe kelimeler birer birer nakşoldukça, onların ruhuna binlerce seneden beri cetlerin tecrübelerinden, felaketlerinden, zaferlerinden, hayat hakkındaki felsefesinden süzülüp gelen bir hülasa, damla damla akmış oluyor""10.
\end{abstract}

Hamdullah Suphi Tanrı̈ver'in Gagauzlara dair bütün tasarruflarının altında işte bu düşünce yatmaktadır. Büyükelçilik görevine başlar başlamaz da Türkçe konuşan Gagauzların Anadolu'ya nakli onun öncelikli arzusu olmuştur. Gerek mübadele kapsamında gerekse münferit olarak Balkanlardan Anadolu'ya devam eden göçlere Gagauzları da dâhil etmek isteyen Hamdullah Suphi Tanrı̈ver, Dış İşleri Bakanlı̆̆ı'na gönderdiği her raporunda mutlaka Gagauzların nakledilmesinden bahsetmiştir. Türk makamlarını göçe ikna edebilmek maksadıyla da raporlarında yaptığı görüşmelere yer veren büyükelçinin şu iki örneği hayli önemlidir; "Sana bir soru soracă̆ım, doğru cevap ver; ĕger Türkiye kapılarını açarsa ve sizi içeri almak isterse gider misin? Bir şey soracă̆ım dedin sanki bu da laf mı? Devlet bizi çă̆ırırsa biz burada niçin sürüneceğiz." Dimitri adında bir Gagauz'un kendisine söylediklerini de şöyle nakletmiştir; "seninle Türkçe konuşuyorum deye klzdl... Bereket bizim orada devletimiz var, babamız var, siz olmasanı bunlar bizi ayakaltında ezerler, ne vakit bizi toplayıp kaldiracaksını""11.

Buraya aldığımız diyaloglar şu açıdan önemlidir; Hamdullah Suphi Tanrı̈ver, muhtemelen idarecilerin yeni tanıdıkları ve kim oldukları hakkında kesin bilgi sahibi olmadıkları fakat sadece Hristiyanlıklarından emin oldukları Gagauzların Türkiye’ye göçüne sıcak bakmayacaklarının farkındadır. Zira nüfus mübadelesini yeni yaşayan, özellikle Ermeni, Rum bakiyesi olan bazı kişilerin yarattığı terör ve şiddet, devlet nezdinde haklı bir hassasiyetin oluşmasına neden olmuştur. Oldukça yakın bir geçmişin tesiriyle karşılaşacağı vaziyeti önceden tahmin edebilen Tanrı̈ver raporlarında önce Gagauzların Türklügüunü ispata çalışmış akabinde de Türkiye'ye göç etme arzusunun onlardan geldiğini göstermeye gayret etmiştir. Tafsilatlı raporunun sonunda Hamdullah Suphi, Türk milletinin ve devletinin kendilerine sahip çıkmalarını istediğini Gagauzlara karşı kayıtsız kalınmaması gerektiğini tarihî, siyasî, kültürel delilleriyle izah etmiştir. Gagauz köylülerinin Türkiye’ye gelmek için toplu dilekçeler yazarak Köstence Konsolosluğuna müracaat ettiklerini beyan eden büyükelçi; "yedi sekiz asırlık bir müddetten beri kendilerini Müslüman Türklere, celbettirecek en ufak bir nüvaziş bile görmemiş olan bu adamlar bugün aile ocaklarının idame ettiği Türk harsı sayesinde hala Türkiye hakkında az çok alaka duymaktadırlar" diyerek asırlardır Anadolu

10 Hamdullah Suphi Tanrı̈ver, Günebakan, İstiklal Matbaası, İzmir 1987, s. 146.

11 CCA. 030.10.246.666.30. 
Türklüğü tarafından haberdar olunmayan ancak Türk dili ve kültürü sayesinde asırlardır var olagelen Gagauzlara artık sahip çıkılması gerektiğini yazmıştır. Hamdullah Suphi Tanrı̈ver'in şu ifadeleri ise kişisel düşünceleri izhar etmesi açısından oldukça önemlidir:

"Gagauzların eski dilleri Kıpçak lehçesine yakın bir Türkçe olarak gösterilmektedir... Bulgaristan'da olanlar, Hristiyanlık dolayıslyla, çocuklarını Bulgar mekteplerine, Romanya'da olanlar ise Romen mekteplerine gönderiyorlar. Ĕger bir Türklük telkini araya girmezse yakın zamana kadar yaşadıkları arazide hâkimiyet kazanan milletlerin bir millileştirme siyaseti olmaması dolayısıla Türklüklerini muhafaza eden bu halk, nihayet bir asır zarfinda, yeni temsil tedbirleri neticesinde tamamen erimeye, dağılmaya mahkûmdur"12.

Görüleceği üzere Suphi Bey, kendi zamanına kadar çeşitli nedenlerle asimilasyondan korunabilmiş Gagauzların artık çok daha büyük tehlikelerle karşı karşıya kalabileceğini, Türklüklerini bunca zaman muhafaza edebilen Gagauzlara, Türkiye Cumhuriyeti'nin sahip çıkmasının elzem olduğunu belirtmiştir. Etimolojik, antropolojik, filolojik ve tarihî açıdan Gagauzların Türklüğünü ispat için yoğun bir gayret sarf eden Suphi Bey raporuna adeta tarihe not düşen şu yorumla son vermiştir:

“Eğer Türk milliyetperverliği, eski Rumeli'nin koskoca bir parçasında asırlardan beri anadillerini sadakatle muhafaza eden bu eyi ahlak sahibi, sağlam ve güzel Türk halkı ile alakadar olmaya başlar ve bunlara tarihi hakikati telkin ile kendilerini Türk camiasina davet ederek başka milletler arasında büsbütün eriyip kaybolmalarına mani olursa ve nihayet ümit ve temenni ettiğim üzere Anadolu'nun kapılarını Türk ırkının bu öz evladına açar ve eski maruf tesamuhuna göre onlara dini hürriyetleriyle beraber yer ve yurt gösterirse boş olan Anadolu kendisine sadakatle ve merbut kalacağl muhakkak olan yepyeni bir kuvvet kazanır. İki bin senelik bir zaman zarfinda putperestlikten, Budistlikten başlayarak Hristiyanlı̆̆a Kırım'daki ve Lehistan'da Karaim Türkleri gibi Museviliğe, Hristiyanlı̆̆a ve Müslümanlığa geçen ve fakat milliyetini ve hürriyetini, ecdadın en kutsi ve en büyük mirası olan ana dili içinde saklayan Türkler, kendi ırklarının bu koskoca parçasını başkalarına kaptırmamalıdırlar. Bulgarlar Bulgarca konuşan, Müslüman Pomaklarl terk etmeye razı olmuyorlar: dinleri Müslümandır, fakat Bulgardırlar bizdendirler diyorlar. Suriye'de Hıristiyan Arap, Müslüman Arapla beraber Fransız istilasına karşı mücadele etmektedir. Hiristiyan Arnavutlar, halkının ekseriyeti Müslüman olan Arnavutluk'un istihlas hareketinde milletlerine sadakatle mücâhede etmişlerdir. Bosna-Hersek teki Sirp mektepleri, Müslüman Boşnak çocuğunu Hiristiyan Sirp çocuklart ile beraber Sirp vatanperveri olarak yetişiyor. Vekâletin Müslüman Türkler hakkında olduğu gibi bu Hıristiyan Türkler hakkında ittihaz buyuracağı kararl ve bendenize tebliğ edeceği emri bekliyorum efendim "'13.

Burada da açıkça görüleceği üzere Hamdullah Suphi Tanrı̈ver'in en büyük kaygısı Gagauzların Hıristiyan olmaları hasebiyle devlet nezdinde kabul görmeme ihtimalidir. $\mathrm{Bu}$ nedenle aynı millet içerisindeki din farklılıklarının sorun olmayacağına dair örnekler vererek

12 CCA. 030.10.246.666.30.

13 CCA. 030.10.246.666.30. 
fikirlerine maddi deliller sunmakta ve olası itirazların önünü kesmeye gayret etmektedir. Ancak maalesef Tanrı̈̈ver kaygılarında haklı çıkacak, bir anlamda korktuğu başına gelecektir. Çünkü hem arşivlerden hem de yaşananlardan görebildiğimiz kadarıyla az sayıda öğrencinin Türkiye’ye eğitim için gönderilmesi, kitap yardımı gibi sembolik sayılabilecek bazı adımların dışında Hamdullah Suphi Bey’in canhıraş gayretleri arzu ettiği düzeyde karşılık bulmamıştır. Devlet ricalinden kendi heyecanına beklediği dönüşleri alamayan, esas yapmak istediklerini yapamayan Suphi Bey planlarını hayata geçirebilmek maksadıyla yeni bir yola başvurmuştur. Basının da gücünü kullanarak, Türk milletine Gagauzların kim olduklarını, içinde bulundukları zor şartları anlatmak istemiştir. Türk matbuatından tanıdı̆̆ı kimseler yardımıyla Türk halkına, Gagauzları tanıtmaya çalışmıştır. Muhtemelen toplumda Gagauzların tanınırlığını artırarak onların Türkiye'ye nakilleri için bir kamuoyu yaratacağını ve devlet ricalinin de buna kayıtsız kalamayacağını düşünmüştür.

Bu bağlamda 14 Temmuz 1935 tarihli Ulus gazetesinde çıkan haber oldukça dikkat çekicidir. Çünkü bu dönemde zaten Romanya'dan, Bulgaristan'dan Müslüman Türkler Anadolu'ya gelmeye devam etmekteydiler ve bu konu ile ilgili pek çok haber farklı gazetelerde çıkmaktaydı. Fakat söz konusu haberin içeriği diğerlerinden oldukça farklıydı. Manşetten verilen haberin başlığ1; "Romanya'dan Gelecek Türk Göçmenler Ne Şartlar İçinde Ne Kadar Zamanda Getirilecekler?"'dir ${ }^{14}$. Bu ilk başta normal bir haber gibi görünebilir. Ancak haberi farklı kılan ilk husus haberin alt başlığıdır. Manşette sadece Romanya'dan gelecek Türklerden bahsedilirken alt başlık hayli farklı atılmıştır; "Romanya'da ne kadar Türk var? Romanya Türkleri nasıl insanlar, onlar hakkında anılar, Gagauzlar, Gagauzların konuştukları Türkçe dil araştırmaları için tükenmez bir hazinedir." Manşetten verilen haberin hemen altında devam eden göç ile alakalı genel bilgiler verilirken beşinci sayfadan itibaren haber tamamıyla Gagauzların kim oldukları, dilleri, menşeleri, ahlakları, karakterleri hakkında tafsilatlı bilgiler veren tanıtıcı yazıya dönüşmüştür. Yazının dikkat çeken bir diğer özelliği ise sonunda yer alan cümlelerle ilgilidir; "Romanya topraklarını 1910'dan beri dört kere gezmiş ve her seferinde Türk halkıyla çok yakından değette bulunmuş bir adam sıfatıyla diyebilirim ki" ${ }^{\prime 5}$. Bu ifadelere göre yazı bizzat sahayı gören biri tarafından kaleme alınmıştır. Tespit edebildiğimiz kadarıyla Hamdullah Suphi Bey 1913 yılında da farklı bir nedenle bölgeyi ziyaret etmiştir ki yazı çıktığında orada görev yapmaktaydı. Şahsi kanaatimiz bu haber kamuoyu yaratma maksadıyla Tanrı̈̈ver tarafından yazılmıştır. Zira haberde vurgulanan hususlar ile onun tanzim ettiği raporların içeriği ve üslubu ciddi benzerlik taşımaktadır.

14 "Romanya'dan Gelecek Türk Göçmenler Ne Şartlar İçinde Ne Kadar Zamanda Getirilecekler", Ulus, 14 Temmuz 1935, s. 1.

15 “Romanya'dan Gelecek Türk Göçmenler", Ulus, 14 Temmuz 1935, s. 5. 
Gönlü Gagauzlar için atan Hamdullah Suphi Tanrı̈ver'in Kasım 1935'te Başbakanlık Müsteşarı olarak görev yapan Kemal Gedeleç’e yazdığı mektuba burada özellikle yer vermek istiyoruz. Mektup Cumhurbaşkanlığ 1 Cumhuriyet Arşivi’ne “Romanya Göçmenleri Hakkında Bükreş Elçisi Hamdullah Suphi Tanrı̈ver'den Alınan Rapor.” başlığı ile kaydedilmiştir. Ancak belgelerin içeriğine bakıldığında görülmüştür ki, Hamdullah Bey ilk sayfalarda devam eden göç ile alakalı kısa bilgiler verdikten sonra sözü 1934-1935 yılında Besarabya' da yaşanan kıtlığa ve Gagauzların maruz kaldıkları felakete getirmiştir:

"Bu yaz Besarabya mintıkası çok ağır bir kutlı̆ga maruz kaldı. Devamlı bir kuraklık neticesi mahsul olmadı ve bu vilayet ahalisi açliktan ölüm tehlikesine maruz kaldı. Romanya cemiyetleri, Romanya gazeteleri bu katlğga ve bunun tesirlerine dair aylardan beri neşriyatta bulunuyor. Zatı aliniz Hristiyan Türk kesafetinin bilhassa Besarabya'da olduğunu bilirsiniz. Başka mintıkalara kaldırılan çocuklar arasında Türkler de vardır. Prens Karaca'nın karısı Madam Kostea Karaca, Elçiliğe müracaat ederek Besarabya'dan Ploeşti'deki çiftliğe naklettiği aç çocuklar arasinda 32 Türk çocuğunun bulunduğunu ve bunların Türkçeden başka hiçbir dil bilmedikleri için her nevi ızdıraplarını anlatmakta müş̧ülat çektiklerini anlatarak benden oraya iki ay kadar hizmet etmek üzere bir Türk hizmetçi aradı̆̆g gibi mümkün ise herhangi bir şekilde yardım da istedi. Besarabya'daki Almanlar için Romanya'nın Alman ekalliyeti ve Yahudiler için diğer Yahudiler umumi bir faaliyete geçtiler. Düşünüyorum ki her nevi yardımdan mahrum olan ve her gün kalbini biraz daha fazla Türkiye' ye çeviren, içinde milli duygusu uyanan bu Hristiyan Türkler için Başbakanımızın lütfedeceği herhangi bir yardım birkaç merkeze münhasır bile olsa bilhassa mahrumiyetin, ızdirabin bu kadar şedit olduğu bir zamanda büyük bir minnettarlık uyandıracaktır. Zatı alinizden bu istirhamımı kendilerine arz etmenizi diliyorum. Iki bin lira, bin beş yüz lira, hatta bin lira böyle günlerde çok büyük fedakârlıkların diğer vaziyetlerde hâsıl edeceği tesiri uyandırabilmek istidadındadır. Üç yüz bin kişilik bir kütleyi Ana vatana bağlamak için her yıl hükümetimizden ne kadar az bir şey istediğimi göz önüne getirerek Başbakanımızı bin dertle meşgul oldukları bir zamanda bir dakika için yakın yıllara gelinceye kadar tamamen bakımsız kalmış bu avare fakat son derece müstenit, son derece verimli Hristiyan Türk kütlesi için meşgul etmek istedim. Ellerinden öptügümü, derin saygllarımı ve sevgilerimi bu dileğimle beraber arz ederek lütfen cevaplarını bana bildiriniz"'16.

Kıtlık ve açlık gibi tarifsiz bir felaket yaşayan Gagauzlara yardım eli uzatılması için Suphi Bey bütün unvanlarını, sıfatlarını kenara atmış adeta yalvarmıştır. Maalesef istediği miktarın da ciddi bir tutar olmadığını arşiv kayıtlarından görmek mümkündür. Zira mektubun muhatabı Kemal Gedeleç, 01.08.1935 tarihli bir belgeye göre Erzincan'da bir gün daha kalacağ1 için kendisine 1.500 lira gönderilmesini istemiştir ${ }^{17}$. Yani söz konusu bürokratın talep ettiği bir günlük harcırah ihtimaldir ki birçok Gagauz için hayati öneme sahiptir. Bu vaziyet devlet içerisinde Gagauzlara bakışa dair önemli bir göstergedir. Hamdullah Suphi Tanrı̈ver'in istediği meblağ devletin göndermekte zorlanacağı bir miktar değildir. Fakat parayı gönderecek kişilerin Gagauzlara bakışı paranın gönderilmemesinde etkili olmuştur.

16 CCA. 030.10.116.810.11.

17 CCA. 30.1000.13.75.12. 
Az evvel yukarıda izah ettiğimiz üzere Hamdullah Suphi Tanrı̈ver zaten bir müddettir yazdıklarına dönüş olmaması sebebiyle basın aracılığıyla toplumda bir şeyleri harekete geçirmeye çalışmaktaydı. Suphi Bey, beklediği cevapları alamama nedeninin Gagauzların dinî durumları olduğunu tahmin etmektedir ki kendi raporlarında 1srarla Gagauz Türkleri ile Anadolu Türklüğü arasında her ne kadar dinsel farklılık olsa da dil, kültür, karakter bakımından herhangi bir fark olmadığını yazmaktaydı. Kemal Gedeleç’ten de beklediği dönüşü alamayan Suphi Bey’in basını daha etkili kullanmaya başladığını söylemek mümkündür.

Mektuptan bir ay sonra yani Aralık 1935'ten itibaren Ulus Gazetesi yazarlarından ama aynı zamanda Hamdullah Suphi Tanrı̈öer'in yakın dostu Yaşar Nabi Nayır'ın kaleminden “Türk Gagauzlar" başlıklı yazı serisi Türk basınında ilk defa Gagauzlar hakkında birinci elden bilgi veren yazılar olmuştur. 22, 23, 25, 26, 31 Aralık 1935 ve 3 Ocak 1936'da çıkan bu yazılar daha sonra Yaşar Nabi Nayır tarafından kitap olarak da yayımlanmıştır. Ancak yazıların ilk yayımlandığı tarihler ve öncesindeki raporlar birlikte okunduğunda söz konusu yazıların yayımlanma zamanı ve içeriği ayrıca önem kazanmaktadır. Bu yazılanların tesadüfen kaleme alındığını düşünmek imkânsızdır. Devlet erkânının Gagauzlara mesafeli durmasının en büyük nedeni onların Ortodoks olmalarıydı. Dinî farklılıklarının hem siyasî hem de kültürel ayrılık yaratacağına dair kaygıları gidermeye yönelik ifadelere yazılarda özenle yer verilmiştir. Öncelikle Gagauzların siyaseten asla sorun çıkarmayacaklarına dair adeta söz verilmiş ve onların Anadolu Türkleri gibi devlete sadakatle bağlı, kuzu gibi insanlar oldukları ifade edilmiştir. İnançlarına dair ise Gagauzların endişe edilecek derecede dindar olmadıkları özellikle vurgulanmıştır. Başıboş bırakıldığı zaman, dinden habersiz yaşar denilerek endişeli gönüllere su serpilmeye çalışılmıştır. Hatta inançlarında eski Türk inanışları olduğu gibi İslamiyet'e ait bazı ibadetlerin de mevcudiyetini vurgulanarak inanç bakımından Anadolu Türklüğünden farklarının olmadıkları örneklerle izah edilmiştir ${ }^{18}$. Yazıların içeriğine bakıldığında altı günlük bu yazı dizisinin Hamdullah Suphi Tanrı̈ver'in amaçları doğrultusunda, birilerine cevap verme ve kamuoyu oluşturma maksadıyla kaleme alındığı açıktır.

Gagauzlar hakkında Yaşar Nabi Nayır'ın yazdıkları gerçekten etkili olmuştur. Çünkü söz konusu yazı dizisine müteakip 18 Ocak 1936 tarihinden itibaren, o sirada Madrid'de

18 Gagauzların, Türk ırkının karakteristiğini gösteren diğer bir vasıflarl da oturduklarl topraklarda, hükümet kimin elinde olursa olsun, daima kanunlara boyun eğen, gürültü ve isyan çıkarmayan kuzu gibi insanlar oluşlarıdır. Bundan başka yapılan telkinlere çok kolay inanır ve bağlanır oluşları da gene itiraz götürmez Türklüklerinin ayrı bir delilidir. Gagauz, Müslüman Türk gibi, taassuplu ve imanlı din adamlarının tesiri altında dindar, başıboş bırakıldığı zaman, dinden habersiz yaşar. Gagauzlar ya en eski Türk itiyatlarını korumuş olmaktan ya da Müslüman Türklerle komşuluklarından kalma alışkanlık eseri olarak bazı İslami âdetlere sahiptirler. Bunlardan en dikkate değer olanı kurban kesmektir. Gagauzlar, Hristiyan dininde böyle bir kaide olmamasına rağmen dini veya ananevi bir vazife telakki ederek kurban kesmekte ve etlerini fakirlere dağıtmaktadırlar. Bunlardan başka fakir ve kimsesizlere gerek para ve gerekse erzak vermek suretiyle yardımda bulunmayı da -zekât ve fitre ile kıyas ediniz-sevap telakki etmekte ve ellerinden geldiği kadar bundan geri kalmamaktadırlar” Nabi, “Türk Gagauzlar”, Ulus, 25 Aralık 1935, s. 4. 
Büyükelçilik görevini ifa eden Tevfik Kâmil Koperler'in doğrudan İsmet İnönü'ye yazdığı mektuplar bunun en önemli delilleridir. Tevfik Kâmil Koperler'in yazdıkları devlet ricalinin kararlarını etkileyecektir. Aynı zamanda hukuk profesörü olan Kâmil Koperler, 2. Lozan Konferansı Türk Delegasyonu Kâtibi Umûmiliğini yapmıştır. Ancak daha da önemlisi Türk Rum Ahali Mübadelesi Türk Heyeti Başkanlığını yürütmüştür ${ }^{19}$. Doğrudan Başbakan İsmet İnönü’ye hitaben yazdığı ve Gagauzların Türk olmadığını ispat ettiğini düşündüğü 18 Kanunisani (Ocak) 1936 tarihli rapor şöyledir:

"Geçenki arizemi takdim ettikten sonra Gagavuzlar için ULUS gazetesinde yedi makale neşirle kalınmayarak radyo ile de Gagavuz müsamereleri tamim edilmiş olduğunu duydum. Hatalı ve hatarl olduğuna emin olduğum bu dava için memlekette şumüllü bir propagandaya girişilmiş bulunduğunu gördügümden bu bahsı bir kere daha kurcalamak için müsaadelerini dilerim... Ankara ve Bursa'nın Ermenileri Türkçe konuşurlar onlara niçin Türk demiyorlar? İzmit havalisinde Rumca konuşur Ermeniler (hay-Rumlar) vardl, onlar da Rum 'durlar deyen olmamıştır. Eski Karaman Rumları ne kadar Türkse Gagavuzlar da o kadar Türk olabilir. Bu adamlar muhitlerindeki Türklerin dilini almıs olmakla neden Türklerden daha kıdemli Türk menzilesine çıkarılsınlar? Seferadit Yahudiler 15inci asrın kastiyyen dilini her türlü eza cefalardan sonra da muhafaza etmişlerdir, bunlar Ispanyol mu sayılacaktır? Realiteye dayanan bunun gibi sayısız misallerden sonra neden biri Bulgar Gagavuz'u (Atanas Manof) olmak üzere Macar veya Rus ulemadan dokuz yabancinın şehadetile, (bu milletin Türk olduğu artık itiraz kabul etmez bir hakikat) haline geçmiş olsun? Bu nasıl ilmi bir hakikattir ki dokuz kişi öyle söylemiş olduğu için başkalarına ağız açtırmak bile istenmiyor? Dogmaların yıkıldığı bir devirde, nice tarihi hakikatler aleyhine yeni deliller ikame olunurken Gagavuz efsanesini bundan müstesna tutulacaktır? Klymeti olmayan bu iddia üzerinde durmayarak diğer iki delillerine geçiyorum:

1-bunların bir arabça ilal idgam kaidesine uygun bir kelime oyunundan başka bir mahiyet göstermiyor (gagvuz aslında gök oğuz idi.)

2- öteki ise Gagavuzların "ulu”su Çakır Keşiş-Mihal'daki milli Türk heyecanı ile (bu heyecandan büyük delil olmaz diyorlar) yine o zatın meşhur Istorya eseri. Yeni bir Kodatko Bilik klymeti verilmek istenen bu muteber teliften menkul şöyle cümleler var ki öz Türkçenin fesahatına, mahvına misal olarak alınmak istenmiştir: (zere olur lazım bilmeklikki Gagavuzlar İsa Tanrı dinini Ortodoks yürütiler, gayet religyalıkl temiz kimselerdir) Bendeniz altmış senedir ıslavlarla temasta kalmış, Türklerle rabıtası kesilmiş Bulgaristanlı Türk köylüleriyle, Almanya'da Protestan misyoneri yapılan Çin Türkistan'indan Kulcalı Rifat Davudla konuştum, onların hiç biri böyle çapraşık, iktidari fiilsiz Türkçe konuşmazlar, bu hatayl yapanlar Türkçeyi müstear dil olarak edinenlerdir Ermeniler ve Gagavuzlar gibi.

Keşişe deyecek yoktur. Papas olmasına rağmen kendini Türk hissedebiliyorsa aferin derim, mümkünse onu Kişinev Ortodoks Metropolidi yaptıralım. Fakat Türkiye’yi Gagavuz kolonisi yapmayalım. Mübadele ve ona tekaddüm eden milli harekât sayesinde milli birliği teessüs

19 https://www.tbmm.gov.tr/TBMM_Album/Cilt4/index.html. 
eder gibi olan memleketimize yeniden bir Ortodoks cemaatı getirmek kendi yaptığımızı yine kendimiz yıkmak, gelecek asırlarda fitne ve suriş unsurlarını biriktirmek olur. Türk gazeteleri bundan sakınmalıdır. Bunu kestiremeyecek kadar dünün acı misallerini unutmuş olanların mazarratına mani olacak hükümettir"'20.

Üç sayfalık rapor doğrudan Ulus gazetesinde Yaşar Nabi’nin yazıları hedef alınarak yazılmıştır. Malum olduğu üzere Nayır tüm yazılarında Gagauzların en az Anadolu Türkleri kadar Türk olduklarını savunmuştur. Nayır'a göre bunun en önemli kanıtı da Gagauzların Türkçe konuşmasıdır ve bu iddia esasında Hamdullah Bey’e ait bir düşüncedir. Buna mukabil Kâmil Koperler de yalnızca dili esas alarak Gagauzların Türk olduklarını iddia etmenin yanlış olacağını farklı örnekler ile anlatmıştır.

Arşive göre 13 gün sonra yani 31 Ocak 1936'da Tevfik Kâmil Koperler'in İnönü’ye hitaben yazılmış ikinci mektubu vardır. Yeni mektubun içeriği daha serttir ve bu sefer hukuki kaidelere göre Gagauzların Türkiye’ye getirilmesinin hatalı olacağı ifade edilmiştir. Zira Koperler bu defa Mübadele Komisyonunun 1927 yılında aldığı mübadillerin milliyetleri gözetilmeksizin "Müslüman Dini” ve "Rum Ortodoks Dini” mensupları olarak görülecektir kararına atıf yapmış ve itirazlarını karar üzerine temellendirmiştir:

\begin{abstract}
“Gagauzları Türkiye’ye getirmek için üç senedir sarf edilmekte olan sebatkâr mesainin bendenizce hatarnak ve zararlı olan bir içtihadın nihayet Hükümete terviç ettirilmiş ve yalnız iskân yerlerinin henüz kararlaşmamış olduğunu kabul etmek lâzım gelecektir. Hâlbuki Keşiş Çakır'in milleti 1923 senesinde Türkiye topraklarında mukim bulunmuş olsaydl, Mübadele Komisyonu onları emsali gibi Yunanistan'a sevke mecbur olacaktı. Malumu Samileridir ki (religion grecque orthodoxe) tabiri Rumlukla alakadar bir şey olmayıb Oecuménique Fener Patrikhanesi, Antakya, İskenderiyye, Kudüs Patrikhaneleri (obédience)ında bulunan her cins ve milletten Hristiyanlara şamildir. Bir an için, bir iki muarızın bunları behemal Türk saymak hakkındaki faraziyelerine iştirak edeyim. Mademki bunlar (grecque orthodoxe) dinindendir, mübadele mevzuuna girecek bir millettir. Nitekim kendilerinden hiçbir farkl olmayan Karamanlı ve Ankaralı kardeşleri de Yunanistan'a ahden sevkedilmişlerdi. Komisyon yalnız Antakya Patrikhanesine merbut (Arapça konuşur) Mersin Ortodokslarını bu tedbirden keyfi olarak istisna etmişti. Ĕ̆er, Hükümetimiz, Türkiye ve Türklükle alakası olmayan bu adamları İstanbul'da iskân etmek istemişse elbette çok isabetli davranmıştır. Patrikhane müntesibi olan bu yabancılar, Yaşar Bey istatistiki tahmini kadar kalabalık bir cemaat iseler, Istanbul'a dolmalart Türk nüfusu aleyhine müvazeneyi bozacak ve Türklerin çoğalmasına değil, öteki kardeşleri firari rumların açık kalmış yerlerini doldurmaya yarayacaktır. Bir misli daha artacak İstanbul Ortodokslarının ilanihaye belediye surları içinde sıkışacaklarını ve Maltepe'den öteye aşamayacaklarını kabul etsek de bu bile İstanbul Türklerinin atisi bakımından vehametli bir ihtimaldir"21.
\end{abstract}

20 CCA. 030.10 .116 .810 .12$.

21 CCA. 030.10.116.810.12. 
Kâmil Koperler'in kaygı dolu ifadelerine göre Suphi Bey amacına ulaşmak üzeredir, yani Gagauzların Türkiye'ye getirilmeleri kararı Hükümet tarafından kabul edilmiştir. Buna karşı Kâmil Bey de hukukçu, dış işleri uzmanı ama daha önemlisi Mübadele Komisyonu Başkanı sıfatıyla Gagauzların gelişinin hukuken imkânsız olduğunu iddia etmiştir. Mübadele kararının alındığı Lozan'da bizzat bulunan Kâmil Bey, yapılması muhtemel göçün Lozan'a da aykırı olacağını açıkça vurgulamıştır. Bir örnekle de durumu açıklığa kavuşturmuş ve Gagauzların, şayet Türkiye'de meskûn olsalardı dahi Ortodoks olmaları hasebiyle Mübadele Anlaşması kapsamında Yunanistan’a gönderileceğini ifade etmiştir.

"Milliyetimiz her şeyden fazla dilimizin içindedir" diyerek Türkçe konuşan Gagauzların Türklüğünü ispat etmek için, Dış İşleri Bakanlığına onlarca sayfa rapor yazan Hamdullah Suphi Tanrı̈öer, kısmen de olsa Gagauzlara yardımcı olabilmiştir. Bununla yetinmeyen Tanrı̈ver, devlet ricalinin daha fazla dikkatini çekmek ve onları Türkiye'ye nakillerine ikna edebilmek için yoğun bir bilgilendirme faaliyetine girişmiştir. Gazete ve radyo aracılığı ile Gagauzların kim olduklarını, Türklüklerini kamuoyuna anlatmıştır. Fakat Tevfik Bey’in, Ulus gazetesinde çıkan Gagauz yazılarından sadece iki hafta sonra kaleme aldığı yazılar devlet erkânının kararını etkilemiştir. O ilk önce Gagauzların Türk olmadıklarını ispat etmeye çalışmış; fakat yazdıkları etkili olmadığında konuyu hukuki zemine çekmiştir. Gagauzların Türk olsalar dahi Ortodoks olmalarını ön plana çıkarmış ve hem Lozan'daki Mübadele Anlaşmasına hem de Mübadele Komisyonunun tanımlarına yer vererek komisyonun kararlarını ırk gözetilmeksizin "Müslüman Dini” ve "Rum Ortodoks Dini” tabiiyetlerine göre vereceğini hatırlatmıştır. Kâmil Bey’in bu çıkışı işe yaramıştır. Çünkü mesele artık uluslararası hukuka dair bir husustur ve yapılan tanımların değiştirilmesi veya esnetilmesi mümkün değildir. Böylece artık Gagauzların millî kimlikleri değil dinî kimlikleri akıbetlerini şekillendirmiştir.

\section{Örtülü Mücadele}

İlgili raporlardan sonra Gagauzlara dair bütün haberler ve yayınlar bir anda kesilmiştir. Fakat Kâmil Bey'in 18 Ocak 1936 tarihli mektubundan sonra Ulus Gazetesi'nde 7 Ağustos 1936'da tek bir yazı çıkmıştır. Yazının başlığı, bürokraside örtülü devam eden mücadeleye alenen cevap gibidir; Muslih Ertaç isimli biri tarafından kaleme alınan, "Gagauz Türklerinin Soylarına Sadıklığı” başlıklı yazı adeta satır satır Kâmil Bey’e cevaptır. Kâmil Bey; "Ankara ve Bursa'nın Ermenileri Türkçe konuşurlar onlara niçin Türk demiyorlar? Seferadit Yahudiler 15inci asrın kastiyyen dilini her türlü eza cefalardan sonra da muhafaza etmişlerdir, bunlar İspanyol mu sayılacaktır? Bu adamlar (Gagauzlar) muhitlerindeki Türklerin dilini almış olmakla neden Türklerden daha kıymetli Türk menzilesine çıkarılsınlar" diyerek Gagauzların Türkçe konuşmalarının onları Türk yapmayacağını yazarken, Muslih Ertaç şöyle yanıt vermiştir: 
"Aynı soydan bir topluluğu böylece din ayrllı̆̆ yüzünden ikiye ayrlmalarına rağmen aralarında birlik, müşterek dilleri olan Türkçe ve müşterek olan anane ve adetlerine bugüne kadar devam etmiştir... Gagauzlar Osmanlı idaresi altında serbest bir hayat yaşlyor ve dilleri, adetleri hususunda kimsenin tazyikına maruz bulunmiyorlardı. Gagauzların din bakımından tâbi oldukları Rumlar, onlart "Türkçe konuşan Rumlar" adiyle anarak temsil etmek gayesini güdüyorlardı fakat millî benliklerinde ısrar eden Gagauzlar Rumlar kendilerine yabancı telakki etmekteydiler. Gagauz köylerine halkı Gagauzlaştırmak hususu maksadıyla gönderilmiş olan muallimler, Türkçeyi ögrenerek ve onların adetlerini edinerek Gagauzlaşmış olarak geri dönüyorlardı. Gagauz köylerinde yerleşen Bulgarlar da onların dil ve adetlerine temessül ederek Gagauzlaşıyor fakat Gagauzları Bulgarlaştırmaya muvaffak olamıyorlardı. Bugün, Bulgaristan'da Gagauzlar, hükümet tarafindan yabancı soydan müstakbel bir topluluk telakki edilmemekte, istatistiklerde Bulgar namı altında zikredilmektedirler. Fakat ancak zevahiri kurtarmaya yartyan bu gibi tedbirlere răgmen Gagauzlar yalnı dillerini, anane ve itiyadlarını muhafaza etmekle kalmıyor, soylarına olan derin ve şuurlu bağlllıklarıyla kendilerine yaklaşanları bile tesirleri altına almakta gecikmiyorlar,"22.

Yine Tevfik Bey raporunda Gagauzların etnik menşeine dair herhangi bir izahatta bulunmadan dinlerine ve Türkçelerine atıf yaparak onların Türk olmadıklarını iddia ederken, Muslih Ertaç aksine; “Orta Asya'dan Balkanlara göçen ırklar arasında Hristiyanlı̆̆ kabul etmiş olan Gagavuz ve Gacallar da bulunmaktadır. Asırlar zarfinda vukua gelen muhtelif evolüsyonlar ve tarihi hadiseler neticesinde bu müşterek kütleden bir kısmı ayrlarak Hristiyanlı̆̆ kabul etmiş (Gagauzlar) diğer bir kısmı da Deliorman'da Müslümanlaşmıştır (Gacallar)” diyerek Gagauzların, tarihî süreçlerin sonunda Hıristiyan olduklarını, sırf bu nedenle onların Deliorman'daki Müslüman Gacallar'dan farklı olmadıklarını ilmî delilleri sıralayarak ispata çalışmıştır.

Bu noktada bazı sorular ortaya çıkmaktadır. Tevfik Bey'in raporuna müteakip Ulus Gazetesi'ndeki Gagauz haberleri bir anda kesilmişken neden yedi ay sonra tek bir yazı yayımlanmış ve sonrasında suskunluk devam etmiştir? Ayrıca yazıyı kim yazmıştır? Muslih Ertaç'ın kim olduğuna ve diğer yazılarına dair derin taramalar yaptığımızda ise ilgili şahsın başka bir yazısının olmadığı görülmüştür. Ötesinde söz konusu kişiye dair hiçbir bilgi de tespit edilememiştir. Bu durumda Muslih Ertaç'ın müstear bir isim olduğunu söylemek mümkündür. Çünkü Arapça Muslih kelimesinin iyileştiren, düzelten, ıslah eden anlamlarına gelmesi bu ismin belli bir maksatla seçildiği kanaatimizi kuvvetlendirmektedir. Şahsi tetkiklerimize göre yazıyı Hamdullah Suphi Tanrı̈over yazmıştır. Çünkü Tevfik Kâmil Koperler'in son mektubuyla, uzun gayretleri neticesinde ikna edebildiği devlet ricali, Gagauzların Anadolu'ya göçürülmesinden vazgeçmiştir.

Özellikle 1935 'ten sonra Hamdullah Suphi Tanrı̈ver'in Gagauzlara yardım edilmesine dair taleplerine karşılık alamaması, halka yönelik yayınlar aracılığıyla Gagauzlara dair alakayı

22 Muhsin Ertaç, “Gagauz Türklerinin Soylarına Sadıklığı”, Ulus, 7 Ağustos 1936, s. 4-5. 
canlandırma çabalarının engellenmesi onu ziyadesiyle üzmüştür. Kalbi Türklük aşkıyla dolu olan ve yukarıda görüldüğü üzere hazırladığı raporlarda olaylara dışarıdan bakan bürokrat tavrının ötesinde yaşananları içselleştirerek aktaran Hamdullah Suphi Tanrı̈ver'in, Tevfik Kâmil Koperler'in raporuna bir cevap vermek istemesi güçlü bir ihtimaldir. Edebiyatçı kişiliği, şahsi tanıdıkları vasıtasıyla Gagauzlara dair son bir yazı kaleme aldığını, bu yazıyı da Muslih gibi manidar bir isimle yayımladığını düşünüyoruz.

Konumuz çerçevesinde Gagauzlara dair son makale 7 Haziran 1938'de Cumhuriyet Gazetesi'nde Yunus Nadi tarafından yayımlanmıştır. “Imparatorluktan Dökülüp Kalan Türkler" başlıklı yazı; "Yeni Türkiye Türklügünün milli zihniyeti behemal bu kardeşlerimiz arasında dahi inkişaf bulmalıdır" sözleriyle başlamış ve şöyle devam etmiştir:

"Yakın ve uzak Türk tarihiyle bütün milletçe biraz fazla, yani layık olduğu derecede ehemmiyetle meşgul olmaya henüz başlayamadı. Romanya'da ve Bulgaristan'daki Gagavuz Hristiyan Türklerini ise daha dün bir, bugün iki yeni keşfettik!... Cumhuriyet Türkiye'sinde her gün kendi benliğimizi biraz daha fazla anladıkça bin zahmetlerle tasfiye oluna oluna nihayet Türklük Türkiye'sinde karar kllan yeni ve muhakkak surette istikbali halinden daha mes'ud olmağa namzed hayatımızın bahar gülleri gibi açılan inşirahları içinde imparatorluktan yâb ellerde dökülüp kalmış ırk kardeşlerimizi üzülerek düşünüyoruz. Yeni Türkiye Türklüğ̈̈nün millî zihniyeti behemehal bu kardeşlerimiz arasinda dahi inkişaf imkânları bulmalıdır. Uzakta kalsınlar, yakına gelsinler ayni parlak istikbalin feyizleri bu kardeşlerimizi de kucaklamalıdır. O feyizlerin getireceği kucaklamalara intizaren ana vatandan cüda Türkleri biz hür ve müstakil Türkiye Türkleri daima birer ağabey sahabetile kucaklamağa mecburuz. Onların hayatlarile alâkadar olmamaklı̆̆ımıza imkân yoktur artık. Açık söyliyelim ki tamamile kültürel olan bu düşüncede siyasî hiçbir kasid ve garazın zerresi mevcud değildir"'23.

Bu yazı ile Suphi Bey’in bütün çabalarının nispeten de olsa karşılık bulduğunu söylemek mümkündür. Nihayet Türkiye, Gagauzları resmen tanımıştır. Yunus Nadi eleştirileri ve yapılması gerekenleri açıkça ifade etmiştir. Ancak yine de hâlâ Gagauzların Hristiyan olmaları meselesi tam olarak sindirilememiştir. Türkiye’ye getirilmeleri hususu tam netleşmediği ve yazının sonunda yer alan "açık söyliyelim ki tamamile kültürel olan bu düşüncede siyasî hiçbir kasid ve garazın zerresi mevcud değildir" cümlesinin bazı eleştirilere tedbir amaçlı yazılmış olduğu çok açıktır. Cumhuriyet Gazetesi'ndeki bu son yazıdan sonra ise Gagauzlara dair ciddi bir haber çıkmamış, neredeyse konu tümüyle kapanmıştır. 1940’lı yıllardaki savaşlar, ekonomik buhranlar, çift kutuplu dünyadaki siyasi gerilimler daha da önemlisi bu sahanın Sovyet denetiminde olması Gagauzlar ile bağlantıya ciddi bir ket vurmuştur. Ancak 1990’l1 yıllarda komünist rejimin ilgası ve özerklik gayretleriyle Türkiye Cumhuriyeti yeniden Gagauzlar ile alakadar olmaya başlamıştır.

23 Yunus Nadi, “İmparatorluktan Dökülüp Kalan Türkler”, Cumhuriyet, 7 Haziran 1938, s. 7. 


\section{Sonuç}

Çarlık Rusya XX. yüzyıl başlarında, Besarabya ve Bucak’taki Müslüman Kıpçakları bölgeden çıkartırken yerine Ortodoks Gagauzları iskân ettiriyordu. Çarlık yönetimi böylece nüfus-din dengesini kendi lehine çevirerek hâkimiyet sahasını genişletmeye çalışıyordu. Ancak muhtemelen öngöremediği bir durum gelişti ve Gagauzların meskûn olması bölgenin etnolinguistik bakımdan yeniden Türkleşmesini sağladı. Şüphesiz daha sonra Mihail Çakır'ın gayretleri Türkleşme sürecini pekiştirmiştir. Çünkü Çakır, Ziya Gökalp'in Türklük-İslam-Çağdaşlık Uygarlık sentezine benzer Türklük-Hıristiyan-Çağdaşlık Uygarlık sentezini geliştirmiştir. Eserleri vasıtasıyla da Türklük bilgi ve bilincini Gagauz kimliğinin bileşenlerinden biri haline getirmiştir. Hatta Gagauzların Türkçe konuşan Bulgar veya Yunan oldukları iddialarını reddederek Türk-Oğuz kökenlerini Gagauz ulusal tezinin esasına yerleştirmiştir ${ }^{24}$. Gagauzların hem dinî hem de siyasî lideri olarak onun inşa ettiği bu kimlik de Gagauzlar tarafindan kabul görmüş ve benimsenmiştir.

Ulusal kimliklerin inşa edildiği bu tarihî süreçte, yeni kurulan Türkiye Cumhuriyeti’nin kurucuları da ulusal bir kimlik tanımladılar. Elbette imparatorluk bakiyesi olan devletin Ortadoğu'dan Balkanlara dağılan nüfustan yeni bir Türk kimliği tesis etmesi sancılı bir süreçti. Her ne kadar Türk kimliğinin ana unsuru etnik öge görülse de aslında bu devirde kurucular için ulusal kimliğin başat ögesi din, İslamiyet olmuştur. Bu, geçmişin bir tezahürü olarak tesis edilmiştir. Çünkü Balkan ulusları kendilerini tanımlarken mutlaka "Ortodoks" olmalarını ön plana çıkarıyorlardı. Milletlerin adeta yeniden inşa edildiği bu yıllarda idareciler de dönemin şartları doğrultusunda Türk kimliğinin ana omurgası olarak "İslam' 1 " seçmiştir. 1927 tarihli Mübadele Komisyonu kararı da bir anlamda bunu resmîleştirmiştir.

Fakat Köstence ve Varna Konsolosları ile Bükreş Büyükelçilerinin 1930'lu yılllarda görev bölgelerindeki Gagauzlara dair faaliyetleri yeni bir kimlik tanımını zaruri kıldı. İlk rapor yazan Ragıp Bey Gagauzlar için; "Bunlar Türk idaresi altında dilleri Türkleşen eski Rumlardan ibaret bir halktır diyenler varsa da bu yanlış bir telakkidir" diyerek onların Türklügünden ilk bahseden kişi olmuştur. Varna Konsolosu 1932'de tanımı daha net hâle getirerek Gagauzları; "Oğuz neslinden bir kitle” olarak tanımlamıştır. Suphi Bey ise neredeyse bütün görev süresi boyunca Gagauzların Türklüğünü devlet erkânına anlatmaya ve onları Türkiye’ye nakletmeye gayret etmiştir. Gerek Dış İşlerine verdiği raporlarla gerekse basının yardımıyla hedefine adım adım yaklaşmakta idi. Ancak 1936 yılında Tevfik Kâmil Bey’in, İsmet İnönü’ye hitaben yazdığı mektuplar, Hamdullah Suphi Tanrı̈ver'in tüm çalışmalarına ket vurmuştur. Kâmil Bey, Gagauzların sırf Türkçe konuştukları için Türk sayılmalarına şiddetle çarşı çıkmıştır. Fakat hükümetin, Gagauz nakline müsaade vereceği ihtimalinin kuvvetlenmesi karşısında

24 Süer Eker, “Türk Dünyasının Bilgeleri Moldova Gagauz Yeri ve Türkiye’yi Birleştiren Anıtsal Bir Kimlik: Mihail Mihailoviç Çakır", Tehlikedeki Diller Dergisi, II/3 (2013), 97-98. 
Mübadele Anlaşmasına atıfta bulunmuştur. Gagauzların, Türkiye'de yaşasalar dahi "Rum Ortodoks Dini”ne mensup olmalarından dolayı anlaşma çerçevesinde zaten Yunanistan'a gönderileceğini yazması, devlet ricalini ikna etmek için yeterli olmuştur. Çünkü mesele artık uluslararası hukuk seviyesinde bir konu haline gelmiş ve Lozan'ın ihlal edilme ihtimali Gagauz göçünün naklini durdurmuştur.

Elimizdeki arşiv malzemesine göre Kâmil Koperler ve Hamdullah Suphi Tanrı̈ver arasında açıktan bir mücadelenin olduğu açıktır. Zira Kâmil Bey, doğrudan gazete ve yazar adı vererek yazılanlara, ayrıca Suphi Bey’e ait olan düşüncelere açıktan itiraz etmiştir. Suphi Bey'in özellikle Türkçe temelli kimlik tanımına şiddetle karşı çıkmıştır. Ancak sözlerini daha etkili kılan ise Lozan'a açıktan muhalefet edileceğini belirtmesi olmuştur. Her iki büyükelçi sahip oldukları imkânlar dâhilinde Başbakan İnönü’yü kendi görüşleri çerçevesinde ikna etmeye çalışmıştır. Fakat Kâmil Bey’in argümanlarının daha güçlü olması sebebiyle Suphi Bey'in tüm gayreti sonuçsuz kalmıştır.

Burada elbette mesele, şahsi bir durumun ötesinde, kimlik ve millet konusunda tanımların farklı olmasıdır. Kâmil Bey, yaptığı görevler ve devletin nüfus sorunu çerçevesinde Türk olsalar dahi Rum Ortodoks nüfusun Türkiye’ye nakline karşı çıkmıştır. İlgili dönemin şartlarında bu hassasiyeti anlamak mümkündür. Suphi Bey’in günümüzde kültür milliyetçiliği olarak tanımlanabilecek ögelerle Türk kimliği tanımlamasının ise o günün koşulları altında kabul edilmemesi de gayet normaldir. Çünkü yukarıda da tafsilatıyla izah edildiği üzere ulusal kimlik her ne kadar modern bir tanım olsa, etnik unsurları ön plana çıkarıyor görünse de din ve ritüeller bir topluluğu birleştiren en önemli değerdir.

Kanaatimize göre, Suphi Bey, Kâmil Bey'in mektubundan haberdar olduktan sonra Muslih Ertaç gibi manidar bir mahlas kullanarak son kez düşüncelerini paylaşmak istemiş olabilir. Zira Suphi Bey’in tüm raporlarındaki düşünceler, ifadeler ile Muslih Ertaç'ın yazısının içeriği ve üslubu tartışmasız bir benzerlik göstermektedir.

\footnotetext{
Hakem Değerlendirmesi: Dış bağımsız.

Çıkar Çatışması: Yazar çıkar çatışması bildirmemiştir.

Finansal Destek: Yazar bu çalışma için finansal destek almadı̆̆ını beyan etmiştir.
}

Peer-review: Externally peer-reviewed.

Conflict of Interest: The author has no conflict of interest to declare.

Grant Support: The author declared that this study has received no financial support. 


\section{Kaynakça/References}

\section{Arşiv Belgeleri}

\section{Cumhurbaşkanlığı Cumhuriyet Arșivi (CCA)}

Hariciye Vekâleti 030.10.16.810.11.

Hariciye Vekâleti 030 10.247.668.22.

Hariciye Vekâleti 030.10.246.666.30.

Hariciye Vekâleti 030.10.247.66814.

Hariciye Vekâleti 030.10.247.668.11.

Hariciye Vekaleti 030 10.247. 668.6.

Hariciye Vekâleti 030.01.02.87.62.7.

Hariciye Vekâleti 030.18.01.02.19.30.8.

Hariciye Vekâleti 03011.1.171.35.17.

\section{Gazeteler}

Cumhuriyet, 3 Nisan 1933; 10 Nisan 1933; 17 Nisan 1933; 7 Haziran 1938.

Ulus, 14 Temmuz 1935; 22 Aralık 1935; 23 Aralık 1935; 25 Aralık 1935; 26 Aralık 1935; 31 Aralık 1935; 3 Ocak 1936; 7 Ağustos 1936.

\section{Kitap ve Makaleler}

Anzerlioğlu, Yonca, "Bükreş Büyükelçisi Hamdullah Suphi ve Gagauz Türkleri”, Bilig, sayı 39 (2006), s. 31-51.

Çil, Adalet Ergenekon, Cumhuriyetin İlk Yıllarında Nüfus Sorunu ve İskân Politikası, Yıldız Teknik Üniversitesi Sosyal Bilimler Enstitüsü, Basılmamış Doktora Tezi, İstanbul 1994.

Dağıstan, Adil, "Hamdullah Suphi'nin Romanya Büyükelçiliği ve Gagauz Türkleri”, Atatürk Araştırma Merkezi Dergisi, XVIII/54 (1992), s. 815-828.

Demir, Murat, Milli Eğitim Bakanı Hamdullah Suphi Tanriöver 'in Eğitim ve Kültür Anlaylşı, Gazi Üniversitesi Eğitim Bilimleri Enstitüsü, Yayınlanmamış Yüksek Lisans Tezi, Ankara 2010.

Duman, Önder, “Atatürk Döneminde Romanya'dan Türk Göçleri (1923-1938)”, Bilig, say1 45 (2008), s. 23-44.

Eker, Süer, “Türk Dünyasının Bilgeleri Moldova Gagauz Yeri ve Türkiye’yi Birleştiren Anıtsal Bir Kimlik: Mihail Mihailoviç Çakır”, Tehlikedeki Diller Dergisi, II/3 (2013), 93-101.

Ülküsal, Müstecip, Dobruca ve Türkler, Türkiye Kültürünü Araştırma Enstitüsü Yayını, Ankara 1966.

Tanrı̈ver, Hamdullah Suphi, Günebakan, İstiklal Matbaası, İzmir 1987.

Yardımc1, Remzi, Atatürkçü Düşüncede Ulusal Kimlik Bilinci Kavramı, İstanbul Üniversitesi Atatürk İlkeleri ve İnkılap Tarihi Enstitüsü, Basılmamış Doktora Tezi, İstanbul 1999.

\section{Elektronik Kaynak}

https://www.tbmm.gov.tr/TBMM_Album/Cilt4/index.html. 